\title{
Metformin as an anti-inflammatory agent: a short review
}

\author{
Robin Kristófi and Jan W Eriksson \\ Department of Medical Sciences, Clinical Diabetes and Metabolism, Uppsala University, Uppsala, Sweden
}

Correspondence should be addressed to J W Eriksson: jan.eriksson@medsci.uu.se

\begin{abstract}
Metformin is a biguanide drug widely used as the initial treatment of type 2 diabetes. Despite its widespread use, its precise mechanisms of action remain incompletely characterised. Its effect in lowering blood glucose is largely related to the suppression of gluconeogenesis in the liver, which is probably accomplished by partial inhibition of the mitochondrial respiratory chain complex 1 with a subsequent increase in intracellular AMP levels and activation of AMP kinase. Several local and systemic antiinflammatory effects of metformin have been described. Many of these effects seem to be mediated by AMP kinase activation and downstream effects inhibiting mTOR and NF- $\ltimes B$ pro-inflammatory signalling cascades. However, there are also studies describing actions independent of AMP kinase action. In this review, we summarise the currently known mechanisms of metformin on inflammatory pathways and the clinical evidence underpinning the use of metformin as a potential anti-inflammatory drug.
\end{abstract}

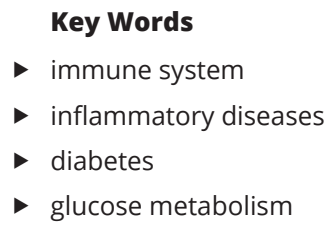

Journal of Endocrinology (2021) 251, R11-R22

\section{Introduction}

Metformin is a biguanide drug that is widely prescribed as an oral antihyperglycaemic agent internationally and is recommended as the initial drug of choice for type 2 diabetes (T2D) according to recent joint European-American clinical guidelines (Buse et al. 2020). Metformin has been used in the treatment of type 2 diabetes since 1958 when it was first introduced to clinical practice in Europe (Bailey 2017). Two other biguanide compounds, phenformin and buformin, were, however, used more widely due to their more potent antihyperglycaemic effects until they were withdrawn in most countries by the late 1970s due to an increased risk of severe lactic acidosis (Stumvoll et al. 2007). All the biguanides are ultimately derived from guanidine, galegine and other related compounds extracted from the plant Galega officinalis (also known as goat's rue, French lilac, Italian fitch, Spanish sainfoin and professor's weed). This plant may have already been used in medieval times as a folk medicine for diabetes-related symptoms such as excessive thirst and urination (Bailey \& Day 2004). As research on the molecular mechanisms of metformin progressed over the years, proposed applications of metformin widened to diverse conditions such as cancer, non-alcoholic fatty liver disease and polycystic ovary disease, although clinical evidence supporting the use of metformin in these diseases is scant (Marshall 2017). It has also been proposed as a general 'anti-ageing' drug based on observations of increased longevity in some, but not all, animals treated with it (Glossmann \& Lutz 2019).

One of the most widely studied aspects of the nonglycaemic effects of metformin is its effects on immune cells and inflammatory processes. This review aims to provide an overview of the preclinical and clinical evidence supporting such immune-modulating and antiinflammatory effects. 


\section{Clinical use and precautions}

The daily dose of metformin used for the treatment of T2D is typically $1-3 \mathrm{~g}$ divided in two to three doses taken orally with major meals. Absorption primarily occurs in the small intestine and the drug is then widely distributed in the body to tissues such as the liver and kidney where uptake is mediated largely by various organic cation transporters (Gong et al. 2012). The drug is excreted unchanged in the urine with an elimination half-life of around $5 \mathrm{~h}$ in subjects with normal renal function (Graham et al. 2011). Although the risk is much smaller than for other biguanides, the accumulation of metformin in the body carries a risk of lactic acidosis. Metformin is, therefore, considered to be contraindicated with a glomerular filtration rate (GFR) of $<30 \mathrm{~mL} / \mathrm{min} / 1.73 \mathrm{~m}^{2}$ and dose reduction is needed at GFR levels of $30-60 \mathrm{~mL} / \mathrm{min} / 1.73 \mathrm{~m}^{2}$ (Imam 2017). In addition, severe impairment of hepatic function is also a contraindication for metformin as it can also increase the risk of lactic acidosis. The chemical structures of metformin and the other biguanide compounds are shown below in Fig. 1.

\section{Glucose-lowering effect}

The effect of metformin to lower blood glucose is primarily mediated by the suppression of hepatic glucose production. Metformin appears to accumulate in mitochondria, preferentially in hepatocytes, and it partially inhibits the mitochondrial respiratory chain complex 1 . This causes intracellular AMP accumulation which in turn activates AMP-activated kinase (AMPK) and leads to inhibition of gluconeogenesis through several downstream pathways (Zhou et al. 2001, Foretz et al. 2019). Other suggested mechanisms include direct inhibition of mitochondrial glycerol 3-phosphate dehydrogenase leading to an increase of cytosolic NAD hydrogen (NADH) levels and altered redox state in hepatocytes. This may also contribute to increased glucagon-like peptide- 1 secretion and decreased gluconeogenesis in intestinal cells (He 2020). There are also result suggesting an increase in local glucose utilisation of the gut (Koffert et al. 2017) as well as potentiation of insulin-mediated glucose uptake in skeletal muscle (Kristensen et al. 2014). Recent research has also postulated a link between metformin treatment and a change in gut microbiota, effects possibly mediated through increased intestinal levels of the bile acid glycoursodeoxycholic acid and antagonism of the farnesoid X receptor (Sun et al. 2018). The quantitative contributions of the several known and potential mechanisms to the overall antihyperglycaemic effect of metformin remain a matter of ongoing research and debate.

\section{Anti-inflammatory effects}

The following sections will provide an overview of the effects of metformin on systemic and local inflammatory responses. We provide an overview of the most important molecular mechanisms of metformin, grouping them into AMPK-dependent and AMPK-independent effects (Fig. 2).

\section{Adipose tissue}

Obesity has been linked to chronic low-grade inflammation in adipose tissue contributing to insulin resistance and ultimately the development of T2D (Wu \& Ballantyne 2020). Targeting this low-grade inflammation may represent an effective way of treating these comorbid<smiles>N=C(N)NC(=N)N</smiles><smiles>CN(C)C(=N)NC(=N)N</smiles>

Biguanide<smiles>CCCCNC(=N)NC(=N)N</smiles><smiles>N=C(N)NC(=N)NCCc1ccccc1</smiles>

Figure 1

Chemical structures of biguanide and its derivatives metformin, buformin and phenformin. https://joe.bioscientifica.com https://doi.org/10.1530/JOE-21-0194 (c) 2021 Society for Endocrinology Published by Bioscientifica Ltd.
Printed in Great Britain
Buformin
Metformin

Phenformin 


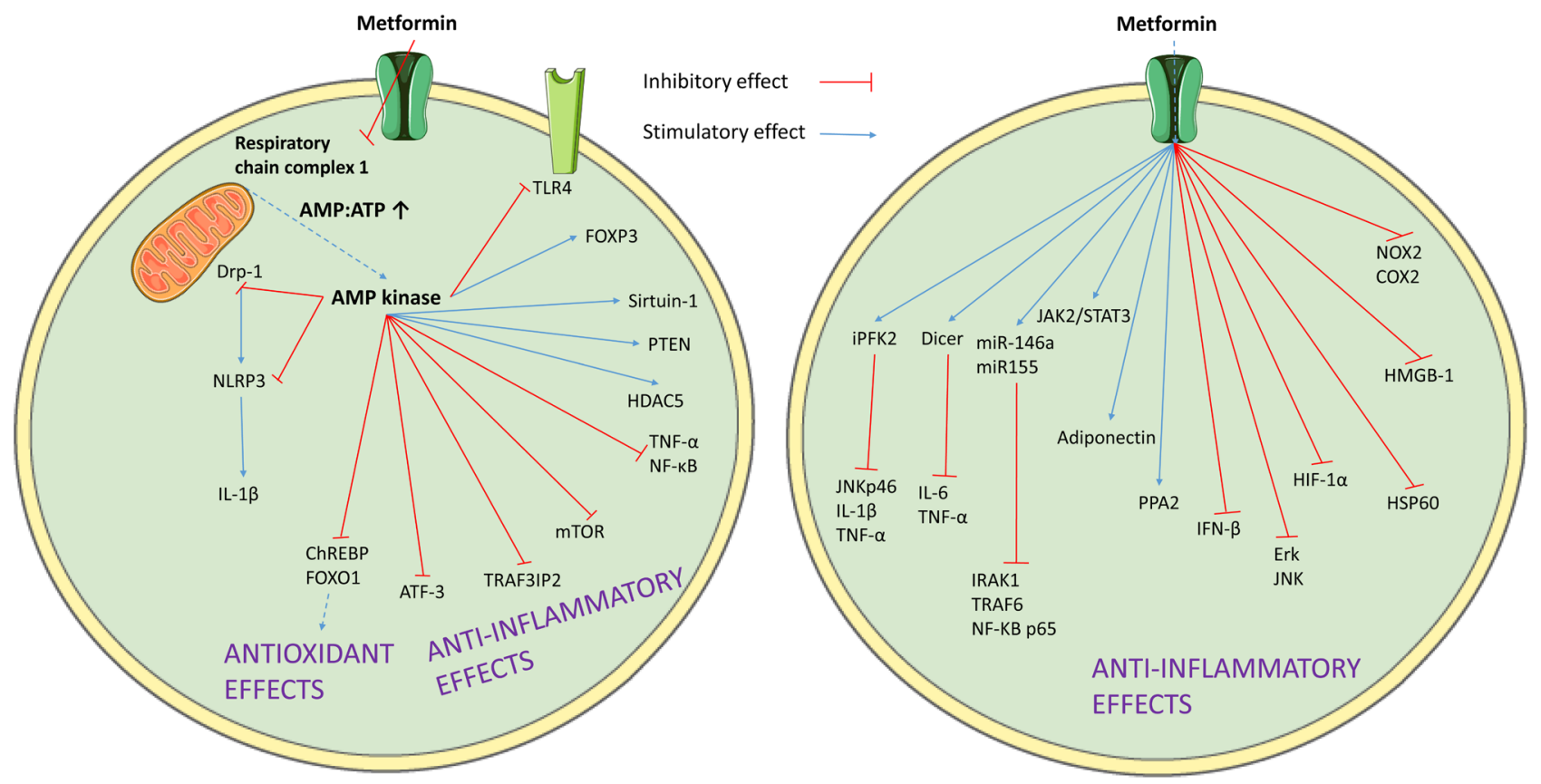

\section{Figure 2}

AMPK-dependent and AMPK-independent cellular effects of metformin. Metformin enters the cell via organic cation transporters and inhibits the respiratory chain complex 1 within the mitochondria leading to an increased intracellular AMP, ATP ratio. This activates AMP kinase and leads to several downstream anti-inflammatory effects, notably including inhibition of the TNF- $\alpha$ /NF- $\kappa$ B and mTOR signalling pathways. Apart from AMPK-mediated effects, several effects have been described that appear to be independent of AMPK action. This includes activation of Dicer, iPFK2 and miRNA leading to lower expression of several pro-inflammatory cytokines such as TNF- $\alpha$ and IL-6. AMPK, AMP kinase; ATF3, activating transcription factor 3; ChREBP, carbohydrate-responsive element-binding protein; COX2, cyclooxygenase 2; Drp-1, dynamin-related protein 1; Erk, extracellular signal-regulated kinase; FOXO1, forkhead box protein 01; FOXP3, forkhead box P3; HDAC5, histone deacetylase 5; HIF-1 $\alpha$, hypoxia-inducible factor-1 $\alpha$; HMGB1, high mobility group box 1; HSP60, heat shock protein 60; IFN- $\beta$, interferon- $\beta$; IL-1 $\beta$, interleukin-1 $\beta$; IL-6, interleukin-6; iPFK2, inducible phosphofructokinase 2; IRAK1, interleukin-1 receptor-associated kinase 1; JAK2, Janus kinase 2; JNK, c-Jun N-terminal kinase; mTOR, mechanistic target of rapamycin; NF-KB, nuclear factor-kappa B; NLRP3, NLR family pyrin domain containing 3; NOX2, NADPH oxidase 2; PPA2, pyrophosphatase 2; PTEN, phosphatase and tensin homologue; TLR4, toll-like receptor 4; TRAF3IP2, TRAF 3 interacting protein 2; TRAF6, TNF receptor-associated factor 6.

conditions. Several models to study adipose inflammation have been used to address metformin effects. Many of these effects appear to be mediated through the activation of AMPK. A study performed in a mouse model of systemic lupus erythematosus (SLE) demonstrated that metformin could enhance immunoregulatory functions of adiposederived mesenchymal stem cells. AMPK activation by metformin led to the inhibition of mechanistic target of rapamycin (mTOR) and activation of signal transducer and activator of transcription 1 (STAT1). Features of lupus nephritis in the animals, such as proteinuria and antidsDNA IgG production, were significantly ameliorated (Jang et al. 2020). In parapancreatic adipose tissue of rats, metformin-mediated AMPK activation inhibited mTOR signalling, which led to a decrease in the levels of the inflammatory cytokines interleukin (IL)-1 $\beta$ and IL17-A. Metformin also induced expression of forkhead box P3 (FOXP3), a master regulator of regulatory $\mathrm{T}$ cells (Treg), which can modulate inflammatory responses and has

(C) 2021 Society for Endocrinology Published by Bioscientifica Ltd.
Printed in Great Britain been shown to ameliorate the severity of autoimmune diseases in animal models (Putilin et al. 2020). In a mouse model, metformin increased AMPK activity in perivascular adipose tissue, leading to increased expression of sirtuin 1 , which is associated with improved insulin sensitivity. It also decreased nuclear factor-kappa B (NF- «B) p65 phosphorylation, leading to lower levels of inflammatory cytokines such as tumor necrosis factor alpha (TNF- $\alpha$ ), IL-6 and C-reactive protein (CRP). In addition, levels of the antiinflammatory adipocyte-derived hormone adiponectin increased and signs of endothelial dysfunction improved (Sun et al. 2014). Another AMPK-mediated effect shown in a study of mice was the inhibition of dynamin-related protein 1 (Drp1)-mediated mitochondrial fission, which prevented stress-induced activation of the NLR family pyrin domain containing 3 (NLRP3) inflammasome. NLRP3 is linked to the initiation and maintenance of inflammation by downstream activation of the important inflammatory cytokine IL-1 $\beta$ (Li et al. 2016a). 
Other studies have identified effects that appear to be independent of AMPK. In rats treated with metformin and in adipose tissue incubated with metformin, levels of hypoxia-inducible factor $1 \alpha$ (HIF- $1 \alpha$ ) and fibrosis markers were reduced (Li et al. 2016b). Metformin did not lower intracellular oxygen tension and was shown to reduce ATP production. This was not seen with another powerful AMPK activator (AICAR), thus suggesting this effect to be AMPK-independent. In experiments with adipocytes in cell culture, metformin was shown to prevent phosphorylation of c-Jun N-terminal kinase (JNK) p46 and lipopolysaccharide-induced gene expression of IL-1 $\beta$ and TNF- $\alpha$ (Qi et al. 2017). Interestingly, these antiinflammatory effects seemed to be mediated by inducible 6-phosphofructokinase-2 (iPFK2) as they were not seen in iPFK2-knockdown adipocytes and there was no increase in AMPK activation. Anti-inflammatory effects were also seen in a mouse model of olanzapine-induced insulin resistance in which metformin not only reduced common inflammatory cytokines such as TNF- $\alpha$, IL-1 $\beta$ and IL-6 but also counteracted macrophage infiltration and M1 polarisation (Guo et al. 2021a). Similar effects have been shown in obese high fat-fed mice with a clear shift in polarisation from M1 to M2 in those animals that received metformin (Jing et al. 2018).

\section{Heart}

Both acute myocardial ischaemia and the development of chronic heart failure are associated with maladaptive inflammatory responses (Adamo et al. 2020) and targeting the IL- $1 \beta$ pathway with the MAB canakinumab has been shown to reduce the risk of cardiovascular events in patients with ischaemic heart disease (Ridker et al. 2017). Metformin has exhibited several anti-inflammatory effects in animal and cell models. In mice, metformin was shown to inhibit aldosterone-induced cardiac fibroblast migration in vitro and to reduce cardiac fibrosis in vivo. This effect was mediated through AMPK activation and inhibition of TRAF 3 interacting protein 2 (TRAF3IP2), an important oxidative stress-responsive adapter molecule that can induce inflammatory cytokines such as IL-17, IL-18 and IL-6 (Mummidi et al. 2016). In mouse studies of heart ischaemia-reperfusion injury, metformin activates AMPK and suppresses NLRP3 inflammasome activity in macrophages which enhances autophagy. This seems to be linked to a protective effect on heart muscle cells from being damaged and dying (Fei et al. 2020, Zhang et al. 2020). However, there is also contradicting evidence that rather implicates a downregulation of autophagy through activation of the Akt signalling pathway as protective metformin effects; different results may be related to differences in methodology, for example, administering metformin prior to ischaemia or during reperfusion (Huang et al. 2020). Another key result of AMPK activation by metformin seems to be inhibition of toll-like receptor 4 (TLR4), leading to significantly lower levels of proinflammatory cytokines and attenuation of left ventricular dysfunction in mouse models of myocardial infarction (Soraya et al. 2012, 2014, Vaez et al. 2016). In accordance with these findings, metformin similarly decreased levels of pro-inflammatory cytokines in a model of endotoxininduced myocarditis (which would act partially through TLR signalling) (Liu et al. 2017). Other studies have shown that metformin may inhibit cardiomyocyte apoptosis by activating the protective, anti-inflammatory Janus kinase 2/signal transducer and activator of transcription 3 (JAK2/STAT3) signalling pathway (Gao et al. 2019) and by activating the mitochondrial pyrophosphatase PPA2 independently of the glycogen synthase kinase 3 beta/ myeloid cell leukemia 1 (GSK3 $\beta / M C L 1)$ pathway (Cheng $\&$ Li 2020). Interestingly, metformin also acts on the epicardial adipose tissue by reducing inflammation and regulating adiponectin signalling which may prevent remodelling and development of atrial fibrillation (Li et al. 2020).

\section{Blood vessels}

Atherosclerosis is considered a chronic inflammatory disease, with accumulation of low-density lipoprotein (LDL) cholesterol in the vessel wall triggering a plethora of immune responses and the formation of atherosclerotic plaques (Wolf \& Ley 2019). The effects of metformin on cells of blood vessels have been extensively researched. An important anti-inflammatory effect is the inhibition of $\mathrm{TNF}-\alpha / \mathrm{NF}-\mathrm{xB}$ signalling. In human umbilical vein endothelial cells, the activation of AMPK by metformin led to inhibition of TNF- $\alpha$ and subsequent NF- $\kappa$ B activation (Hattori et al. 2006, Huang et al. 2009). AMPK activation in endothelial cells may furthermore be enhanced by the activation of phosphatidylinositol 3-kinase (PI3K) (Huang et al. 2009), an effect not seen in vascular smooth muscle cells (Isoda et al. 2006). In a sepsis model of endotoxininduced endothelial inflammation, AMPK activation by metformin led to histone deacetylase 5 (HDAC5) phosphorylation and subsequent upregulation of Krüppellike factor 2 (KLF2), which inhibited TNF- $\alpha$ (Tian et al. 2019). Another effect of metformin-induced AMPK activity appears to be inhibition of the nuclear factors carbohydrate 
response element-binding protein (ChREBP) and forkhead box protein O1 (FOXO1), leading to decreased expression of thioredoxin-interacting protein (TXNIP), which in turn leads to reduced cellular oxidative stress and so could exert a protective effect on vascular endothelium (Li et al. 2015). Recent evidence also points to the role of metformin and AMPK in promoting autophagic flux to counteract intracellular lipid accumulation and thereby to reduce proinflammatory responses (Kim et al. 2020).

In vascular smooth muscle cells, metformin inhibited IL-1 $\beta$-induced activation of NF- $\kappa \mathrm{B}$, the MAP kinases Akt, p38 and Erk, but not, as mentioned previously, activity of PI3K (Isoda et al. 2006). However, a later study was able to show that metformin-induced AMPK action resulted in the activation of phosphatase and tensin homologue (PTEN), a known negative PI3K regulator, and this suppressed the TNF- $\alpha /$ NF- $\kappa$ B pro-inflammatory signalling cascade (Kim \& Choi 2012).

Several animal models have similarly shown beneficial effects of metformin on vascular inflammation associated with the process of atherosclerosis. For instance, in atherosclerotic mice treated with metformin, AMPK activation reduced the expression of Drp- 1 which in turn suppressed mitochondrial fission, attenuated oxidative stress, ameliorated endothelial dysfunction and inhibited vascular inflammation (Wang et al. 2017). In hypertensive rats, metformin exhibited anti-inflammatory effects by reducing plasma TNF- $\alpha$ levels and tissue NADPH oxidase 2 (NOX2) as well as cyclooxygenase 2 (COX2) expression while also improving parameters of cardiac autonomic dysfunction (Oliveira et al. 2020). Interestingly, in a study of rats fed a high-fat diet, it appears that metformin could exert anti-inflammatory effects on the endothelium by increasing levels of the micro-RNAs miR-146a and miR155, in turn decreasing expression of IL-1 receptor-associated kinase1 (IRAK1), TNF receptor-associated factor 6 (TRAF6) and NF- $\kappa \mathrm{B}$ p65. These molecules are crucial components of the pro-inflammatory NF-kB pathway (Gou et al. 2020). Furthermore, in atherosclerotic rabbits, metformin treatment decreased plasma inflammatory cytokine levels and reduced atherosclerotic lesion burden. Analysis of atherosclerotic plaques revealed significantly reduced macrophage content in the metformin-treated animals and attenuation of the pro-inflammatory cytokines monocyte chemoattractant protein 1 (MCP1), IL-6 and TNF- $\alpha$ (Yang et al. 2018). Another study in mice showed that metformin-induced AMPK activation negatively regulates STAT3 activity, which inhibited both inflammation and monocyte-to-macrophage differentiation. Similarly, plaque formation in the metformin-treated animals was attenuated, with reduced monocyte infiltration (Vasamsetti et al. 2015).

\section{Macrophages/monocytes}

Macrophages and monocytes are cells of the innate immune system that play a crucial role in the host defence against pathogens. They have also been implicated in the pathogenesis of inflammatory disorders such as atherosclerosis and obesity. Several effects of metformin on these cells have been described. As for other mechanisms detailed above, AMPK seems to be an important mediator. In a mouse macrophage study, metformin treatment of lipopolysaccharide-stimulated macrophages induced AMPK activation, suppressed the NF- $\kappa \mathrm{B}$ pathway and reduced expression of the chemokines MCP1, C-X-C motif chemokine ligand 10 (CXCL10) and CXCL11 (Ye et al. 2018). Suppression of NF- $k B$ signalling in macrophages was also shown in other studies, along with inhibition of the mitogen-activated protein (MAP) kinases such as Erk and JNK (Bułdak et al. 2016, Wang et al. 2020). AMPK activation by metformin has been shown to counteract the effect of advanced glycation end products (AGE) in promoting inflammation through the receptor for advanced glycation end products (RAGE)/NF- $\kappa \mathrm{B}$ pathway and also to induce $\mathrm{M} 2$ polarisation in murine macrophages. M2 macrophages help resolve inflammation and promote immune tolerance (Zhou et al. 2016). Further experiments have also shown the role of AMPK in increasing the expression of activated transcription factor-3 (ATF-3) which in turn could reduce IL- 6 and TNF- $\alpha$ expression and so reduce inflammation by attenuating macrophage activation (Kim et al. 2014). In PTEN-knockdown murine macrophages, metformin not only blocked reactive oxygen species (ROS) generation and Akt activation but also led to significant apoptosis causing growth inhibition (Lin et al. 2013).

Interestingly, the effects of metformin to inhibit the inducible nitric oxide synthase (iNOS) and thereby reducing ROS formation appear to be independent of AMPK but rather mediated through inhibition of interferon- $\beta$ in the myeloid differentiation primary response 88 (MyD88)independent signalling pathway (Kato et al. 2010). Another AMPK-independent effect of metformin is the direct binding to and inhibition of the alarmin high mobility group box 1 (HMGB1), which induces inflammation by stimulating various receptors such as TLR4 and RAGE (Horiuchi et al. 2017). Studies in endotoxaemic mice have indicated that metformin can also inhibit the release of HMGB1, which, however, is mediated by AMPK (Tsoyi et al. 2011). Furthermore, it has been shown that metformin can 
suppress IL- 6 and TNF- $\alpha$ by inducing Dicer, a key miRNA enzyme, and thereby increasing levels of miR-34a-5p and miR-125b-5p (Luo et al. 2020). NF-kB pathway inhibition may be further mediated by the suppression of scavenger receptors in macrophages such as cluster of differentiation 36 (CD36) and scavenger receptor A (SR-A) (Hyun et al. 2013). Finally, in human monocyte cells, metformin has exhibited strong stimulatory effects on the expression of the mitochondrial chaperone protein heat shock protein 60 (HSP60) (Tsuei \& Martinus 2012). In macrophages, downregulation of HSP60 has been associated with an increased oxidised LDL accumulation and M1 polarisation, which could substantially contribute to the atherosclerotic process in vessel walls (Shirsath et al. 2021).

\section{T cells/B cells/APCs}

T cells, B cells and antigen-presenting cells (APC) play a central role in adaptive immunity. Dysfunctional responses by these cells have been implicated in a wide array of autoimmune diseases. In mouse T cells, metformin exhibited antioxidant effects by reducing intracellular lipid peroxidation and increasing glutathione levels, which resulted in inhibition of T-cell proliferation (Solano et al. 2008). Metformin has furthermore been shown to suppress mechanistic target of rapamycin complex 1 (mTORC1) signalling in mouse CD8 ${ }^{+} \mathrm{T}$ lymphocytes in an AMPK-independent manner, a key pathway involved in the growth and proliferation of antigen-activated $\mathrm{T}$ cells (Zarrouk et al. 2014). In CD4 $4^{+} \mathrm{T}$ cells from both human healthy controls and patients with SLE, metformin inhibited transcription of interferon-stimulated genes by inhibiting phosphorylation of pSTAT1 and its binding to interferon-stimulated response elements. These effects were independent of AMPK activation or mTORC1 inhibition but rather appeared to be mediated through inhibition of mitochondrial respiratory chain complexes (Titov et al. 2019).

Antigen-presenting cells such as dendritic cells play an important role in T-cell activation and primary T-cell responses. Metformin has, in mouse dendritic cells, been shown to decrease MHC class I- and class II-restricted ovalbumin presentation while also suppressing the expression of MHC molecules and co-stimulatory factors such as CD54, CD80 and CD86 (Shin et al. 2013).

Much research has focused on the effects of metformin in animals models of various autoimmune diseases. Interestingly, a study in mice with autoimmune insulitis, a model of type 1 diabetes, showed that metformin reduced the severity of insulitis by suppressing the proliferation of pro-inflammatory Th1 and Th17 cells while promoting the development of Tregs. This was mediated through activation of AMPK and subsequent inhibition of mTOR/HIF-1 $\alpha$ signalling (Duan et al. 2019). Similar findings have been demonstrated in mice with the multiple sclerosis model autoimmune encephalomyelitis (Nath et al. 2009, Sun et al. 2016). In autoimmune arthritis, metformin not only favourably affects the Th17/Treg balance but also promotes brown adipose tissue differentiation, induces fibroblast growth factor 21 (FGF21) expression, suppresses osteoclastogenesis, and corrects impaired autophagic flux (Kang et al. 2013, Son et al. 2014, Yan et al. 2015, Kim et al. 2018).

In a murine SLE model, apart from affecting T cells, metformin could inhibit $B$ cell differentiation into plasma cells, germinal centre formation and decrease autoantibody levels through AMPK activation and inhibition of the mTOR-STAT3 pathway (Lee et al. 2017). This has similarly been shown in a model of Sjögren's syndrome (Kim et al. 2019).

\section{Clinical studies}

\section{T2D and obesity}

In the United Kingdom Prospective Diabetes Study (UKPDS) trial, metformin treatment led to a significantly lower risk of diabetes-related death and adverse diabetesrelated outcomes in overweight T2D patients as compared to diet intervention or treatment with sulphonylurea or insulin (UKPDS Group 1998). The decrease in diabetesrelated endpoints included events of atherosclerotic cardiovascular disease, where chronic, low-grade inflammation is an important pathogenic factor. Thus, it was later hypothesised that the anti-inflammatory effects of metformin may be partly responsible for its beneficial effect. In the Hyperinsulinaemia: the Outcome of its Metabolic Effect (HOME) trial, 390 insulin-treated T2D patients were randomised to either metformin or placebo. Sixteen weeks of metformin treatment led to improvement in several blood plasma markers of endothelial function, but no decrease in the inflammatory parameters CRP and soluble intercellular adhesion molecule-1 (sICAM1) (De Jager et al. 2005). It is noteworthy that the long-term follow-up of this trial showed a significant decrease in the secondary composite macrovascular endpoint in the metformin-treated group (Kooy et al. 2009). Conversely, the A Diabetes Outcome Pogression Trial (ADOPT) study showed that glyburide treatment led to fewer serious 
cardiovascular events as compared to either metformin or rosiglitazone treatment, although the trial was not powered to detect a significant difference in cardiovascular events (Kahn et al. 2006). In a study of T2D patients, 4 weeks of metformin treatment led to a decrease in plasminogen activator inhibitor-1 (PAI-1) and leptin levels, but not in CRP, indicating effects on adipose tissue (Eriksson et al. 2007). Another study involving non-obese patients with T2D utilised a crossover design to compare the effects of metformin and the insulin secretagogue repaglinide. With glycaemic levels being similar in both groups, metformin led to significantly lower levels of TNF- $\alpha$ and SICAM-1, but not CRP or IL-6 (Lund et al. 2008). The effect of metformin was further compared with the thiazolidinedione drug rosiglitazone in a randomised trial. At the end of 12 weeks, serum levels of IL- 6 and TNF- $\alpha$ had decreased significantly in both groups compared to baseline, but there was no difference between the groups (Fidan et al. 2011). Another trial compared the effects on inflammatory parameters after 1 year of treatment with the $\alpha$-glucosidase inhibitor acarbose and metformin. There were no significant differences between the groups although in both, compared to baseline, there were significant decreases in TNF- $\alpha$ and IL-6, but not in IL-2 and IL-1 $\beta$ (Mo et al. 2019).

In an open-label study of overweight individuals with impaired glucose tolerance, half of the participants received the $\beta$-hydroxy $\beta$-methylglutaryl-coenzyme A (HMG-CoA) reductase inhibitor simvastatin and the other half received metformin. After 16 weeks, both groups exhibited significant decreases in CRP and IL- 6 as compared to baseline, with no change in TNF- $\alpha$ and no significant differences between the groups (Bulcão et al. 2007). Further placebo-controlled studies in patients with prediabetes and lipid-lowering drugs showed antiinflammatory effects. Persons with impaired fasting glucose treated with simvastatin were randomised to either placebo or metformin $3 \mathrm{~g}$ daily for 90 days, and metformin treatment resulted in reduced plasma levels of CRP and sICAM1 while also inhibiting lymphocyte release of IL-2, IFN- $\gamma$ and TNF- $\alpha$ (Krysiak \& Okopien 2012). A similar trial in patients with impaired glucose tolerance treated with fenofibrate showed that metformin reduced plasma CRP levels and also suppressed lymphocyte release of IFN- $\gamma$ and TNF- $\alpha$, although sICAM1 levels and IL-2 release were not significantly affected (Krysiak et al. 2013). A study of T2D patients demonstrated significantly lower serum CRP levels compared to placebo, along with reduced oxidative and nitrosative stress (Chakraborty et al. 2011). Conversely, an earlier study involving obese T2D patients did not show any changes in serum levels of CRP and IL-6 after 12 weeks of metformin treatment (Ersoy et al. 2008). Interestingly, however, there is also some evidence that increased metformin dosages may exert greater anti-inflammatory effects. In a crosssectional study of metformin-treated T2D patients, those taking $3000 \mathrm{mg} /$ day had significantly lower serum levels of TNF- $\alpha$ than those treated with 1000 or $2000 \mathrm{mg} /$ day (Amoani et al. 2021).

In another T2D study, treatment with 500-2000 $\mathrm{mg} /$ day metformin led to significantly lower levels of NF- $\kappa B$, IL- $1 \beta$ and the nicotinic acid receptor GPR109A in peripheral blood leukocytes (Xu et al. 2017). In patients with carotid artery atherosclerosis, most of whom were free from diabetes, metformin at a dose of $1000 \mathrm{mg} /$ day led to a significant decrease in plasma levels of hsCRP, IL-6 and TNF- $\alpha$. In peripheral blood mononuclear cells, this effect appeared to be mediated by induction of sirtuin 1 , leading to reduced p65 acetylation and inhibition of NF- $x \mathrm{~B}$ activation (Xu et al. 2015).

\section{Inflammatory and autoimmune diseases}

Metformin has also been proposed as an adjunct treatment in classical inflammatory and autoimmune diseases. In a trial of patients receiving glucocorticoid treatment for various chronic inflammatory diseases, 12 weeks of treatment with metformin $2550 \mathrm{mg} /$ day resulted in lower serum levels of high-sensitive CRP as compared to placebo. Furthermore, carbohydrate-challenged TNF- $\alpha$ levels increased significantly in the placebo-treated group but not in the metformin-treated group (Pernicova et al. 2020). However, a larger trial involving SLE patients did not show a significant decrease in the incidence of lupus flares in the metformin-treated group (Sun etal. 2020). In a translational gout study, it was shown that metformin could inhibit mTOR signalling in monocytes exposed to monosodium urate crystals and metformin use was associated with a lower flare frequency in a retrospective analysis of 42 gout patients (Vazirpanah et al. 2019). Metformin has also been tried as an adjunct therapy for patients with chronic obstructive pulmonary disease (COPD). In a trial of 52 patients hospitalised for severe COPD exacerbations, 1 month of metformin therapy did, however, not result in any reduction of CRP or improvement in clinical outcomes (Hitchings et al. 2016). Other inflammatory conditions where metformin use has been proposed include asthma (Guo et al. 2021b), non-alcoholic steatohepatitis (Li et al. 2019) and inflammatory bowel disease (Lee et al. 2015). However, prospective clinical trials in these disorders are lacking. 
Table 1 Summary of clinical studies of metformin effects on inflammatory markers in humans.

\begin{tabular}{|c|c|}
\hline Reference & Subjects \\
\hline $\begin{array}{l}\text { (De Jager et al. 2005, } \\
\text { Kooy et al. 2009) }\end{array}$ & 390 insulin-treated T2D patients \\
\hline (Eriksson et al. 2007) & 21 T2D patients \\
\hline (Lund et al. 2008) & 96 non-obese T2D patients \\
\hline (Fidan et al. 2011) & 40 T2D patients \\
\hline (Mo et al. 2019) & 70 T2D patients \\
\hline (Bulcão et al. 2007) & $\begin{array}{l}41 \text { overweight individuals with } \\
\text { impaired glucose tolerance }\end{array}$ \\
\hline $\begin{array}{l}\text { (Krysiak \& Okopien } \\
\text { 2012) }\end{array}$ & $\begin{array}{l}62 \text { simvastatin-treated patients } \\
\text { with impaired fasting glucose }\end{array}$ \\
\hline (Krysiak et al. 2013) & $\begin{array}{l}80 \text { fenofibrate-treated patients } \\
\text { with impaired glucose tolerance }\end{array}$ \\
\hline $\begin{array}{l}\text { (Chakraborty et al. } \\
\text { 2011) }\end{array}$ & 208 T2D patients \\
\hline (Ersoy et al. 2008) & 24 obese T2D patients \\
\hline (Amoani et al. 2021) & $\begin{array}{l}209 \text { metformin-treated T2D } \\
\text { patients }\end{array}$ \\
\hline (Xu et al. 2017) & 117 T2D patients \\
\hline (Xu et al. 2015) & $\begin{array}{l}42 \text { patients with carotid artery } \\
\text { atherosclerosis }\end{array}$ \\
\hline (Pernicova et al. 2020) & $\begin{array}{l}53 \text { patients receiving } \\
\text { glucocorticoid treatment for } \\
\text { chronic inflammatory diseases }\end{array}$ \\
\hline (Sun et al. 2020) & 140 SLE patients \\
\hline $\begin{array}{l}\text { (Vazirpanah et al. } \\
\text { 2019) }\end{array}$ & 42 gout patients \\
\hline (Hitchings et al. 2016) & 52 hospitalised COPD patients \\
\hline
\end{tabular}

\begin{tabular}{|c|c|}
\hline Intervention & Effects \\
\hline Metformin vs placebo & $\begin{array}{l}\text { No effect on CRP, sICAM1 at } 16 \text { weeks; lower } \\
\text { risk of secondary composite macrovascular } \\
\text { endpoint at } 4.3 \text { years of follow-up }\end{array}$ \\
\hline Metformin vs placebo & $\begin{array}{l}\downarrow \text { PAI-1, leptin, } \\
\text { no effect CRP }\end{array}$ \\
\hline $\begin{array}{l}\text { Metformin vs } \\
\text { repaglinide }\end{array}$ & $\downarrow T N F-\alpha$, sICAM-1, no effect CRP, IL-6 \\
\hline $\begin{array}{l}\text { Metformin vs } \\
\text { rosiglitazone }\end{array}$ & $\begin{array}{l}\downarrow \text { IL-6, TNF- } \alpha \text { compared to baseline; no } \\
\text { difference between groups }\end{array}$ \\
\hline $\begin{array}{l}\text { Metformin vs } \\
\text { acarbose }\end{array}$ & $\begin{array}{l}\downarrow \text { TNF- } \alpha \text { and IL- } 6 \text {, no effect IL- } 2 \text { and IL- } 1 \beta \\
\text { compared to baseline; no difference } \\
\text { between groups }\end{array}$ \\
\hline $\begin{array}{l}\text { Metformin vs } \\
\text { simvastatin }\end{array}$ & $\begin{array}{l}\downarrow \text { CRP and IL-6, no effect TNF- } \alpha \text { compared to } \\
\text { baseline; no difference between groups }\end{array}$ \\
\hline Metformin vs placebo & $\begin{array}{l}\downarrow \text { CRP, sICAM } 1 \\
\downarrow \text { lymphocyte release of IL-2, IFN- } \gamma, \text { TNF- } \alpha\end{array}$ \\
\hline Metformin vs placebo & $\begin{array}{l}\downarrow \text { CRP } \\
\downarrow \text { lymphocyte release of IFN- } \gamma \text { and TNF- } \alpha \text {, no } \\
\text { effect ICAM1, IL-2 }\end{array}$ \\
\hline Metformin vs placebo & $\begin{array}{l}\downarrow \text { CRP } \\
\downarrow \text { oxidative and nitrosative stress }\end{array}$ \\
\hline No control group & No effect CRP, IL-6 \\
\hline Cross-sectional study & $\begin{array}{l}\downarrow \text { TNF- } \alpha \text { in } 3000 \text { mg/day group compared to } \\
1000-2000 \mathrm{mg} / \text { day }\end{array}$ \\
\hline Metformin vs placebo & $\begin{array}{l}\downarrow N F-\kappa B, \text { IL-1 } \beta, \text { GPR109A in peripheral } \\
\text { leukocytes }\end{array}$ \\
\hline Metformin vs placebo & $\downarrow$ hsCRP, IL-6, TNF- $\alpha$ \\
\hline Metformin vs placebo & $\begin{array}{l}\downarrow \mathrm{CRP}, \\
\text { no increase in carbohydrate-challenged TNF- } c\end{array}$ \\
\hline Metformin vs placebo & No effect on SLE flare frequency \\
\hline Cross-sectional study & $\downarrow$ gout flares with metformin use \\
\hline letformin vs placebo & No effect on CRP levels or clinical outcomes \\
\hline
\end{tabular}

The findings of the clinical studies are summarised in Table 1.

\section{Antimicrobial effects}

An intriguing aspect of metformin is its antimicrobial effects shown in several preclinical models, including against Mycobacterium tuberculosis (Rodriguez-Carlos et al. 2020), Staphylococcus aureus (Garnett et al. 2013, Kalsi et al. 2019), zika and dengue virus (Farfan-Morales et al. 2021). In the currently ongoing coronavirus pandemic, COVID19 , metformin has been suggested as an adjunct therapy regardless of diabetes status. This is based on its known anti-inflammatory properties (Samuel et al. 2021). While there are some observational data suggesting a lower risk of death in COVID-19 among metformin-treated women with obesity or T2D (Bramante et al. 2021), this has not yet been shown in any prospective clinical studies.
Several randomised controlled trials are currently being conducted to examine this further (Samuel et al. 2021).

\section{Conclusions}

Metformin is a compound that has been used for several decades in the treatment of T2D, but its molecular mechanisms of action have been explored only in the last few decades. At the cellular level, it consistently exhibits anti-inflammatory actions largely due to its effects to modulate mitochondrial function and thus increasing intracellular AMP levels and thereby activating AMPK. However, several effects that are independent of AMPK have also been described. Apart from its established indication as a drug for type 2 diabetes, it may hold promise as part of adjunct therapy for several classical inflammatory diseases. Additional prospective, randomised clinical trials in larger https://joe.bioscientifica.com

https://doi.org/10.1530/JOE-21-0194 (c) 2021 Society for Endocrinology Published by Bioscientifica Ltd. Printed in Great Britain 
cohorts are required to establish the clinical efficacy of metformin in these disorders.

\section{Declaration of interest}

J W E has received honoraria or research support from AstraZeneca, llya Pharma, MSD, and Novo Nordisk. R K declares no conflicts of interest.

\section{Funding}

This review was partly supported by grants from the Swedish Diabetes Foundation (project 2019-490), the Ernfors Foundation, the Swedish Heart and Lung Foundation (project 2019-0403), the Swedish Research Council project (KBF-2018-00904) and governmental ALF funds.

\section{Author contribution statement}

Both authors participated in writing the manuscript and took final responsibility in the decision to submit for publication.

\section{References}

Adamo L, Rocha-Resende C, Prabhu SD \& Mann DL 2020 Reappraising the role of inflammation in heart failure. Nature Reviews: Cardiology 17 269-285. (https://doi.org/10.1038/s41569-019-0315-x)

Amoani B, Sakyi SA, Mantey R, Laing EF, Ephraim RD, Sarfo-Katanka O \& Koffie S 2021 Increased metformin dosage suppresses proinflammatory cytokine levels in systemic circulation and might contribute to its beneficial effects. Journal of Immunoassay and Immunochemistry 42 252-264. (https://doi.org/10.1080/15321819.202 $0.1862861)$

Bailey CJ 2017 Metformin: historical overview. Diabetologia 60 1566-1576. (https://doi.org/10.1007/s00125-017-4318-z)

Bailey CJ \& Day C 2004 Metformin: its botanical background. Practical Diabetes International 21 115-117. (https://doi.org/10.1002/pdi.606)

Bramante CT, Ingraham NE, Murray TA, Marmor S, Hovertsen S, Gronski J, McNeil C, Feng R, Guzman G, Abdelwahab N, et al. 2021 Metformin and risk of mortality in patients hospitalised with COVID-19: a retrospective cohort analysis. Lancet: Healthy Longevity 2 e34-e41. (https://doi.org/10.1016/S2666-7568(20)30033-7)

Bulcão C, Ribeiro-Filho FF, Sañudo A \& Ferreira SGR 2007 Effects of simvastatin and metformin on inflammation and insulin resistance in individuals with mild metabolic syndrome. American Journal of Cardiovascular Drugs 7 219-224. (https://doi.org/10.2165/00129784200707030-00007)

Bułdak Ł, Machnik G, Bułdak RJ, Łabuzek K, Bołdys A \& Okopień B 2016 Exenatide and metformin express their anti-inflammatory effects on human monocytes/macrophages by the attenuation of MAPKs and NFkB signaling. Naunyn-Schmiedeberg's Archives of Pharmacology 389 1103-1115. (https://doi.org/10.1007/s00210-016-1277-8)

Buse JB, Wexler DJ, Tsapas A, Rossing P, Mingrone G, Mathieu C, D'Alessio DA \& Davies MJ 2020 Correction to: 2019 update to: management of hyperglycaemia in type 2 diabetes, 2018. A consensus report by the American Diabetes Association (ADA) and the European Association for the Study of diabetes (EASD). Diabetologia 631667. (https://doi.org/10.1007/s00125-020-05151-2)

Chakraborty A, Chowdhury S \& Bhattacharyya M 2011 Effect of metformin on oxidative stress, nitrosative stress and inflammatory biomarkers in type 2 diabetes patients. Diabetes Research and Clinical Practice 93 56-62. (https://doi.org/10.1016/j.diabres.2010.11.030)

Cheng G \& Li L 2020 High-glucose-induced apoptosis, ROS production and pro-inflammatory response in cardiomyocytes is attenuated by metformin treatment via PP2A activation. Journal of Biosciences $\mathbf{4 5}$ 1-11. (https://doi.org/10.1007/s12038-020-00096-5)

De Jager J, Kooy A, Lehert P, Bets D, Wulffelé MG, Teerlink T, Scheffer PG, Schalkwijk CG, Donker AJM \& Stehouwer CDA 2005 Effects of shortterm treatment with metformin on markers of endothelial function and inflammatory activity in type 2 diabetes mellitus: a randomized, placebo-controlled trial. Journal of Internal Medicine 257 100-109. (https://doi.org/10.1111/j.1365-2796.2004.01420.x)

Duan W, Ding Y, Yu X, Ma D, Yang B, Li Y, Huang L, Chen Z, Zheng J \& Yang C 2019 Metformin mitigates autoimmune insulitis by inhibiting Th1 and Th17 responses while promoting Treg production. American Journal of Translational Research 11 2393-2402.

Eriksson A, Attvall S, Bonnier M, Eriksson JW, Rosander B \& Karlsson FA 2007 Short-term effects of metformin in type 2 diabetes. Diabetes, Obesity and Metabolism 9 330-336. (https://doi.org/10.1111/j.14631326.2006.00611.x)

Ersoy C, Kiyici S, Budak F, Oral B, Guclu M, Duran C, Selimoglu H, Erturk E, Tuncel E \& Imamoglu S 2008 The effect of metformin treatment on VEGF and PAI- 1 levels in obese type 2 diabetic patients. Diabetes Research and Clinical Practice 81 56-60. (https://doi.org/10.1016/j. diabres.2008.02.006)

Farfan-Morales CN, Cordero-Rivera CD, Osuna-Ramos JF, MonroyMuñoz IE, De Jesús-González LA, Muñoz-Medina JE, HurtadoMonzón AM, Reyes-Ruiz JM \& del Ángel RM 2021 The antiviral effect of metformin on zika and dengue virus infection. Scientific Reports 11 8743. (https://doi.org/10.1038/s41598-021-87707-9)

Fei Q, Ma H, Zou J, Wang W, Zhu L, Deng H, Meng M, Tan S, Zhang H, Xiao X, et al. 2020 Metformin protects against ischaemic myocardial injury by alleviating autophagy-ROS-NLRP3-mediated inflammatory response in macrophages. Journal of Molecular and Cellular Cardiology 145 1-13. (https://doi.org/10.1016/j.yjmcc.2020.05.016)

Fidan E, Onder Ersoz H, Yilmaz M, Yilmaz H, Kocak M, Karahan C \& Erem C 2011 The effects of rosiglitazone and metformin on inflammation and endothelial dysfunction in patients with type 2 diabetes mellitus. Acta Diabetologica 48 297-302. (https://doi.org/10.1007/s00592-011-0276-y)

Foretz M, Guigas B \& Viollet B 2019 Understanding the glucoregulatory mechanisms of metformin in type 2 diabetes mellitus. Nature Reviews: Endocrinology 15 569-589. (https://doi.org/10.1038/s41574-019-0242-2)

Gao H, Wu D, Zhang E, Liang T, Meng X, Chen L \& Wu Y 2019 Phasic change and apoptosis regulation of jak2/stat 3 pathway in a type 2 diabetic rat model. American Journal of Translational Research 11 911-930.

Garnett JP, Baker EH, Naik S, Lindsay JA, Knight GM, Gill S, Tregoning JS \& Baines DL 2013 Metformin reduces airway glucose permeability and hyperglycaemia-induced Staphylococcus aureus load independently of effects on blood glucose. Thorax 68 835-845. (https://doi.org/10.1136/ thoraxjnl-2012-203178)

Glossmann HH \& Lutz OMD 2019 Metformin and aging: a review. Gerontology 65 581-590. (https://doi.org/10.1159/000502257)

Gong L, Goswami S, Giacomini KM, Altman RB \& Klein TE 2012 Metformin pathways: pharmacokinetics and pharmacodynamics. Pharmacogenetics and Genomics 22 820-827. (https://doi.org/10.1097/ FPC.0b013e3283559b22)

Gou L, Liu G, Ma R, Regmi A, Zeng T, Zheng J, Zhong X \& Chen L 2020 High fat-induced inflammation in vascular endothelium can be improved by abelmoschus esculentus and metformin via increasing the expressions of miR-146a and miR-155. Nutrition and Metabolism 1735. (https://doi.org/10.1186/s12986-020-00459-7)

Graham GG, Punt J, Arora M, Day RO, Doogue MP, Duong JK, Furlong TJ, Greenfield JR, Greenup LC, Kirkpatrick CM, et al. 2011 Clinical pharmacokinetics of metformin. Clinical Pharmacokinetics 50 81-98. (https://doi.org/10.2165/11534750-000000000-00000) https://joe.bioscientifica.com

https://doi.org/10.1530/JOE-21-0194 (c) 2021 Society for Endocrinology Published by Bioscientifica Ltd. Printed in Great Britain 
Guo C, Liu J \& Li H 2021a Metformin ameliorates olanzapine-induced insulin resistance via suppressing macrophage infiltration and inflammatory responses in rats. Biomedicine and Pharmacotherapy 133 110912. (https://doi.org/10.1016/j.biopha.2020.110912)

Guo Y, Shi J, Wang Q, Hong L, Chen M, Liu S, Yuan X \& Jiang S $2021 b$ Metformin alleviates allergic airway inflammation and increases Treg cells in obese asthma. Journal of Cellular and Molecular Medicine 25 2279-2284. (https://doi.org/10.1111/jcmm.16269)

Hattori Y, Suzuki K, Hattori S \& Kasai K 2006 Metformin inhibits cytokineinduced nuclear factor $\kappa \mathrm{B}$ activation via AMP-activated protein kinase activation in vascular endothelial cells. Hypertension 47 1183-1188. (https://doi.org/10.1161/01.HYP.0000221429.94591.72)

He L 2020 Metformin and systemic metabolism. Trends in Pharmacological Sciences 41 868-881. (https://doi.org/10.1016/j.tips.2020.09.001)

Hitchings AW, Lai D, Jones PW, Baker EH \& Metformin in COPD Trial Team 2016 Metformin in severe exacerbations of chronic obstructive pulmonary disease: a randomised controlled trial. Thorax 71 587-593. (https://doi.org/10.1136/thoraxinl-2015-208035)

Horiuchi T, Sakata N, Narumi Y, Kimura T, Hayashi T, Nagano K, Liu K, Nishibori M, Tsukita S, Yamada T, et al. 2017 Metformin directly binds the alarmin HMGB1 and inhibits its proinflammatory activity. Journal of Biological Chemistry 292 8436-8446. (https://doi.org/10.1074/jbc. M116.769380)

Huang NL, Chiang SH, Hsueh CH, Liang YJ, Chen YJ \& Lai LP 2009 Metformin inhibits TNF- $\alpha$-induced I $k B$ kinase phosphorylation, I $k$ B- $\alpha$ degradation and IL-6 production in endothelial cells through PI3Kdependent AMPK phosphorylation. International Journal of Cardiology 134 169-175. (https://doi.org/10.1016/j.ijcard.2008.04.010)

Huang KY, Que JQ, Hu ZS, Yu YW, Zhou YY, Wang L, Xue YJ, Ji KT \& Zhang XM 2020 Metformin suppresses inflammation and apoptosis of myocardiocytes by inhibiting autophagy in a model of ischemiareperfusion injury. International Journal of Biological Sciences $\mathbf{1 6}$ 2559-2579. (https://doi.org/10.7150/ijbs.40823)

Hyun B, Shin S, Lee A, Lee S, Song Y, Ha NJ, Cho KH \& Kim K 2013 Metformin down-regulates TNF- $\alpha$ secretion via suppression of scavenger receptors in macrophages. Immune Network 13 123-132. (https://doi.org/10.4110/in.2013.13.4.123)

Imam TH 2017 Changes in metformin use in chronic kidney disease. Clinical Kidney Journal 10 301-304. (https://doi.org/10.1093/ckj/sfx017)

Isoda K, Young JL, Zirlik A, MacFarlane LA, Tsuboi N, Gerdes N, Schönbeck U \& Libby P 2006 Metformin inhibits proinflammatory responses and nuclear factor- $\kappa \mathrm{B}$ in human vascular wall cells. Arteriosclerosis, Thrombosis, and Vascular Biology 26 611-617. (https:// doi.org/10.1161/01.ATV.0000201938.78044.75)

Jang SG, Lee J, Hong SM, Kwok SK, Cho ML \& Park SH 2020 Metformin enhances the immunomodulatory potential of adipose-derived mesenchymal stem cells through STAT1 in an animal model of lupus. Rheumatology 59 1426-1438. (https://doi.org/10.1093/rheumatology/ kez631)

Jing Y, Wu F, Li D, Yang L, Li Q \& Li R 2018 Metformin improves obesityassociated inflammation by altering macrophages polarization. Molecular and Cellular Endocrinology 461 256-264. (https://doi. org/10.1016/j.mce.2017.09.025)

Kahn SE, Haffner SM, Heise MA, Herman WH, Holman RR, Jones NP, Kravitz BG, Lachin JM, O'Neill MC, Zinman B, et al. 2006 Glycemic durability of rosiglitazone, metformin, or glyburide monotherapy. New England Journal of Medicine 355 2427-2443. (https://doi.org/10.1056/ NEJMoa066224)

Kalsi KK, Garnett JP, Patkee W, Weekes A, Dockrell ME, Baker EH \& Baines DL 2019 Metformin attenuates the effect of Staphylococcus aureus on airway tight junctions by increasing $\mathrm{PKC} \zeta$-mediated phosphorylation of occludin. Journal of Cellular and Molecular Medicine 23 317-327. (https://doi.org/10.1111/jcmm.13929)

Kang KY, Kim YK, Yi H, Kim J, Jung HR, Kim IJ, Cho JH, Park SH, Kim HY \& Ju JH 2013 Metformin downregulates Th17 cells differentiation and attenuates murine autoimmune arthritis. International
Immunopharmacology 16 85-92. (https://doi.org/10.1016/j. intimp.2013.03.020)

Kato Y, Koide N, Komatsu T, Tumurkhuu G, Dagvadorj J, Kato K \& Yokochi T 2010 Metformin attenuates production of nitric oxide in response to lipopolysaccharide by inhibiting MyD88-independent pathway. Hormone and Metabolic Research 42 632-636. (https://doi. org/10.1055/s-0030-1255033)

Kim SA \& Choi HC 2012 Metformin inhibits inflammatory response via AMPK-PTEN pathway in vascular smooth muscle cells. Biochemical and Biophysical Research Communications 425 866-872. (https://doi. org/10.1016/j.bbrc.2012.07.165)

Kim J, Kwak HJ, Cha JY, Jeong YS, Rhee SD, Kim KR \& Cheon HG 2014 Metformin suppresses lipopolysaccharide (LPS)-induced inflammatory response in murine macrophages via activating transcription factor-3 (ATF-3) induction. Journal of Biological Chemistry 289 23246-23255. (https://doi.org/10.1074/jbc.M114.577908)

Kim EK, Lee SH, Lee SY, Kim JK, Jhun JY, Na HS, Kim SY, Choi JY, Yang CW, Park SH, et al. 2018 Metformin ameliorates experimental-obesityassociated autoimmune arthritis by inducing FGF21 expression and brown adipocyte differentiation. Experimental and Molecular Medicine 50 e432. (https://doi.org/10.1038/emm.2017.245)

Kim JW, Kim SM, Park JS, Hwang SH, Choi JW, Jung KA, Ryu JG, Lee SY, Kwok SK, Cho M, et al. 2019 Metformin improves salivary gland inflammation and hypofunction in murine Sjögren's syndrome. Arthritis Research and Therapy 21 1-11. (https://doi.org/10.1186/s13075019-1904-0)

Kim HS, Ren G, Kim T, Bhatnagar S, Yang Q, Bahk YY \& Kim JA 2020 Metformin reduces saturated fatty acid-induced lipid accumulation and inflammatory response by restoration of autophagic flux in endothelial cells. Scientific Reports 10 13523. (https://doi.org/10.1038/ s41598-020-70347-w)

Koffert JP, Mikkola K, Virtanen KA, Andersson AD, Faxius L, Hällsten K, Heglind M, Guiducci L, Pham T, Silvola JMU, et al. 2017 Metformin treatment significantly enhances intestinal glucose uptake in patients with type 2 diabetes: results from a randomized clinical trial. Diabetes Research and Clinical Practice 131 208-216. (https://doi.org/10.1016/j. diabres.2017.07.015)

Kooy A, De Jager J, Lehert P, Bets D, Wulffelé MG, Donker AJM \& Stehouwer CDA 2009 Long-term effects of metformin on metabolism and microvascular and macrovascular disease in patients with type 2 diabetes mellitus. Archives of Internal Medicine 169 616-625. (https:// doi.org/10.1001/archinternmed.2009.20)

Kristensen JM, Treebak JT, Schjerling P, Goodyear L \& Wojtaszewski JFP 2014 Two weeks of metformin treatment induces AMPK-dependent enhancement of insulin-stimulated glucose uptake in mouse soleus muscle. American Journal of Physiology: Endocrinology and Metabolism 306 E1099-E1109. (https://doi.org/10.1152/ajpendo.00417.2013)

Krysiak R \& Okopien B 2012 Lymphocyte-suppressing and systemic antiinflammatory effects of high-dose metformin in simvastatin-treated patients with impaired fasting glucose. Atherosclerosis 225 403-407. (https://doi.org/10.1016/j.atherosclerosis.2012.09.034)

Krysiak R, Gdula-Dymek A \& Okopien B 2013 Lymphocyte-suppressing, endothelial-protective and systemic anti-inflammatory effects of metformin in fenofibrate-treated patients with impaired glucose tolerance. Pharmacological Reports 65 429-434. (https://doi.org/10.1016/ S1734-1140(13)71018-1)

Lee SY, Lee SH, Yang EJ, Kim EK, Kim JK, Shin DY \& Cho M-L 2015 Metformin ameliorates inflammatory bowel disease by suppression of the stat 3 signaling pathway and regulation of the between Th17/ Treg balance. PLoS ONE 10 1-12. (https://doi.org/10.1371/journal. pone.0135858)

Lee SY, Moon SJ, Kim EK, Seo HB, Yang EJ, Son HJ, Kim JK, Min JK, Park SH \& Cho ML 2017 Metformin suppresses systemic autoimmunity in Roquin $^{\text {san/san }}$ mice through inhibiting B cell differentiation into plasma cells via regulation of AMPK/mTOR/STAT3. Journal of Immunology 198 2661-2670. (https://doi.org/10.4049/jimmunol.1403088) https://joe.bioscientifica.com https://doi.org/10.1530/JOE-21-0194 (c) 2021 Society for Endocrinology Published by Bioscientifica Ltd. Printed in Great Britain 
Li X, Kover KL, Heruth DP, Watkins DJ, Moore WV, Jackson K, Zang M, Clements MA \& Yan Y 2015 New insight into metformin action: regulation of chREBP and FOXO1 activities in endothelial cells Molecular Endocrinology 29 1184-1194. (https://doi.org/10.1210/ ME.2015-1090)

Li A, Zhang S, Li J, Liu K, Huang F \& Liu B 2016a Metformin and resveratrol inhibit Drp1-mediated mitochondrial fission and prevent ER stressassociated NLRP3 inflammasome activation in the adipose tissue of diabetic mice. Molecular and Cellular Endocrinology 434 36-47. (https:// doi.org/10.1016/j.mce.2016.06.008)

Li X, Li J, Wang L, Li A, Qiu Z, Qi LW, Kou J, Liu K, Liu B \& Huang F 2016 b The role of metformin and resveratrol in the prevention of hypoxiainducible factor $1 \alpha$ accumulation and fibrosis in hypoxic adipose tissue. British Journal of Pharmacology 173 2001-2015. (https://doi. org/10.1111/bph.13493)

Li YL, Li XQ, Wang YD, Shen C \& Zhao CY 2019 Metformin alleviates inflammatory response in non-alcoholic steatohepatitis by restraining signal transducer and activator of transcription 3-mediated autophagy inhibition in vitro and in vivo. Biochemical and Biophysical Research Communications 513 64-72. (https://doi.org/10.1016/j. bbrc.2019.03.077)

Li B, Po SS, Zhang B, Bai F, Li J, Qin F, Liu N, Sun C, Xiao Y, Tu T, et al. 2020 Metformin regulates adiponectin signalling in epicardial adipose tissue and reduces atrial fibrillation vulnerability. Journal of Cellular and Molecular Medicine 24 7751-7766. (https://doi.org/10.1111/jcmm.15407)

Lin CF, Young KC, Bai CH, Yu BC, Ma CT, Chien YC, Su HC, Wang HY, Liao CS, Lai HW, et al. 2013 Blockade of reactive oxygen species and Akt activation is critical for anti-inflammation and growth inhibition of metformin in phosphatase and tensin homolog-deficient RAW264.7 cells. Immunopharmacology and Immunotoxicology 35 669-677. (https:// doi.org/10.3109/08923973.2013.837059)

Liu G, Wu K, Zhang L, Dai J, Huang W, Lin L, Ge P, Luo F \& Lei H 2017 Metformin attenuated endotoxin-induced acute myocarditis via activating AMPK. International Immunopharmacology 47 166-172. (https://doi.org/10.1016/j.intimp.2017.04.002)

Lund SS, Tarnow L, Stehouwer CDA, Schalkwijk CG, Teerlink T, Gram J, Winther K, Frandsen M, Smidt UM, Pedersen O, et al. 2008 Impact of metformin versus repaglinide on non-glycaemic cardiovascular risk markers related to inflammation and endothelial dysfunction in nonobese patients with type 2 diabetes. European Journal of Endocrinology 158 631-641. (https://doi.org/10.1530/EJE-07-0815)

Luo X, Hu R, Zheng Y, Liu S \& Zhou Z 2020 Metformin shows antiinflammatory effects in murine macrophages through Dicer/ microribonucleic acid-34a-5p and microribonucleic acid-125b-5p. Journal of Diabetes Investigation 11 101-109. (https://doi.org/10.1111/ jdi.13074)

Marshall SM 201760 years of metformin use: a glance at the past and a look to the future. Diabetologia 60 1561-1565. (https://doi.org/10.1007/ s00125-017-4343-y)

Mo D, Liu S, Ma H, Tian H, Yu H, Zhang X, Tong N, Liao J \& Ren Y 2019 Effects of acarbose and metformin on the inflammatory state in newly diagnosed type 2 diabetes patients: a one-year randomized clinical study. Drug Design, Development and Therapy 13 2769-2776. (https:// doi.org/10.2147/DDDT.S208327)

Mummidi S, Das NA, Carpenter AJ, Kandikattu H, Krenz M, Siebenlist U, Valente AJ \& Chandrasekar B 2016 Metformin inhibits aldosteroneinduced cardiac fibroblast activation, migration and proliferation in vitro, and reverses aldosterone + salt-induced cardiac fibrosis in vivo. Journal of Molecular and Cellular Cardiology 98 95-102. (https://doi. org/10.1016/j.yjmcc.2016.07.006)

Nath N, Khan M, Paintlia MK, Singh I, Hoda MN \& Giri S 2009 Metformin attenuated the autoimmune disease of the central nervous system in animal models of multiple sclerosis. Journal of Immunology $\mathbf{1 8 2}$ 8005-8014. (https://doi.org/10.4049/jimmunol.0803563)

Oliveira PWC, de Sousa GJ, Birocale AM, Gouvêa SA, de Figueiredo SG, de Abreu GR \& Bissoli NS 2020 Chronic metformin reduces systemic and local inflammatory proteins and improves hypertension-related cardiac autonomic dysfunction. Nutrition, Metabolism, and Cardiovascular Diseases 30 274-281. (https://doi.org/10.1016/j.numecd.2019.09.005)

Pernicova I, Kelly S, Ajodha S, Sahdev A, Bestwick JP, Gabrovska P, Akanle O, Ajjan R, Kola B, Stadler M, et al. 2020 Metformin to reduce metabolic complications and inflammation in patients on systemic glucocorticoid therapy: a randomised, double-blind, placebo-controlled, proof-of-concept, phase 2 trial. Lancet: Diabetes and Endocrinology 8 278-291. (https://doi.org/10.1016/S2213$8587(20) 30021-8)$

Putilin DA, Evchenko SY, Fedoniuk LY, Tokarskyy OS, Kamyshny OM, Migenko LM, Andreychyn SM, Hanberher II \& Bezruk TO 2020 The influence of metformin to the transcriptional activity of the mTOR and FOX3 genes in parapancreatic adipose tissue of streptozotocininduced diabetic rats. Journal of Medicine and Life 13 50-55. (https://doi. org/10.25122/jml-2020-0029)

Qi T, Chen Y, Li H, Pei Y, Woo SL, Guo X, Zhao J, Qian X, Awika J, Huo Y, et al. 2017 A role for PFKFB3/iPFK2 in metformin suppression of adipocyte inflammatory responses. Journal of Molecular Endocrinology 59 49-59. (https://doi.org/10.1530/JME-17-0066)

Ridker PM, Everett BM, Thuren T, MacFadyen JG, Chang WH, Ballantyne C, Fonseca F, Nicolau J, Koenig W, Anker SD, et al. 2017 Antiinflammatory therapy with canakinumab for atherosclerotic disease. New England Journal of Medicine 377 1119-1131. (https://doi.org/10.1056/ NEJMoa1707914)

Rodriguez-Carlos A, Valdez-Miramontes C, Marin-Luevano P, GonzálezCuriel I, Enciso-Moreno JA \& Rivas-Santiago B 2020 Metformin promotes Mycobacterium tuberculosis killing and increases the production of human $\beta$-defensins in lung epithelial cells and macrophages. Microbes and Infection 22 111-118. (https://doi. org/10.1016/j.micinf.2019.10.002)

Samuel SM, Varghese E \& Büsselberg D 2021 Therapeutic potential of metformin in COVID-19: reasoning for its protective role. Trends in Microbiology (https://doi.org/10.1016/j.tim.2021.03.004).

Shin S, Hyun B, Lee A, Kong H, Han S, Lee CK, Ha NJ \& Kim K 2013 Metformin suppresses MHC-restricted antigen presentation by inhibiting co-stimulatory factors and MHC molecules in APCs. Biomolecules and Therapeutics 21 35-41. (https://doi.org/10.4062/ biomolther.2012.094)

Shirsath K, Joshi A, Vohra A \& Devkar R 2021 HSP60 knockdown exerts differential response in endothelial cells and monocyte derived macrophages during atherogenic transformation. Scientific Reports 11 1086. (https://doi.org/10.1038/s41598-020-79927-2)

Solano ME, Sander V, Wald MR \& Motta AB 2008 Dehydroepiandrosterone and metformin regulate proliferation of murine Tlymphocytes. Clinical and Experimental Immunology 153 289-296. (https://doi. org/10.1111/j.1365-2249.2008.03696.x)

Son HJ, Lee J, Lee SY, Kim EK, Park MJ, Kim KW, Park SH \& Cho ML 2014 Metformin attenuates experimental autoimmune arthritis through reciprocal regulation of Th17/Treg balance and osteoclastogenesis. Mediators of Inflammation 2014 973986. (https:// doi.org/10.1155/2014/973986)

Soraya H, Farajnia S, Khani S, Rameshrad M, Khorrami A, Banani A, MalekiDizaji N \& Garjani A 2012 Short-term treatment with metformin suppresses toll like receptors (TLRs) activity in isoproterenol-induced myocardial infarction in rat: are AMPK and TLRs connected? International Immunopharmacology 14 785-791. (https://doi. org/10.1016/j.intimp.2012.10.014)

Soraya H, Clanachan AS, Rameshrad M, Maleki-Dizaji N, GhaziKhansari M \& Garjani A 2014 Chronic treatment with metformin suppresses toll-like receptor 4 signaling and attenuates left ventricular dysfunction following myocardial infarction. European Journal of Pharmacology 737 77-84. (https://doi.org/10.1016/j. ejphar.2014.05.003)

Stumvoll M, Häring HU \& Matthaei S 2007 Metformin. Endocrine Research 32 39-57. (https://doi.org/10.1080/07435800701743828) https://joe.bioscientifica.com

https://doi.org/10.1530/JOE-21-0194 (c) 2021 Society for Endocrinology Published by Bioscientifica Ltd. Printed in Great Britain 
Sun Y, Li J, Xiao N, Wang M, Kou J, Qi L, Huang F, Liu B \& Liu K 2014 Pharmacological activation of AMPK ameliorates perivascular adipose/ endothelial dysfunction in a manner interdependent on AMPK and SIRT1. Pharmacological Research 89 19-28. (https://doi.org/10.1016/j. phrs.2014.07.006)

Sun Y, Tian T, Gao J, Liu X, Hou H, Cao R, Li B, Quan M \& Guo L 2016 Metformin ameliorates the development of experimental autoimmune encephalomyelitis by regulating T helper 17 and regulatory T cells in mice. Journal of Neuroimmunology 292 58-67. (https://doi.org/10.1016/j. jneuroim.2016.01.014)

Sun L, Xie C, Wang G, Wu Y, Wu Q, Wang X, Liu J, Deng Y, Xia J, Chen B, et al. 2018 Gut microbiota and intestinal FXR mediate the clinical benefits of metformin. Nature Medicine 24 1919-1929. (https://doi. org/10.1038/s41591-018-0222-4)

Sun F, Wang HJ, Liu Z, Geng S, Wang HT, Wang X, Li T, Morel L, Wan W, Lu L, et al. 2020 Safety and efficacy of metformin in systemic lupus erythematosus: a multicentre, randomised, double-blind, placebocontrolled trial. Rheumatology 2 e210-e216. (https://doi.org/10.1016/ S2665-9913(20)30004-7)

Tian R, Li R, Liu Y, Liu J, Pan T, Zhang R, Liu B, Chen E, Tang Y \& Qu H 2019 Metformin ameliorates endotoxemia-induced endothelial proinflammatory responses via AMPK-dependent mediation of HDAC5 and KLF2. Biochimica et Biophysica Acta: Molecular Basis of Disease 1865 1701-1712. (https://doi.org/10.1016/j.bbadis.2019.04.009)

Titov AA, Baker HV, Brusko TM, Sobel ES \& Morel L 2019 Metformin inhibits the Type 1 IFN response in human CD $4+\mathrm{T}$ cells. Journal of Immunology 203 338-348. (https://doi.org/10.4049/ jimmunol.1801651)

Tsoyi K, Jang HJ, Nizamutdinova IT, Kim YM, Lee YS, Kim HJ, Seo HG, Lee JH \& Chang KC 2011 Metformin inhibits HMGB1 release in LPStreated RAW 264.7 cells and increases survival rate of endotoxaemic mice. British Journal of Pharmacology 162 1498-1508. (https://doi. org/10.1111/j.1476-5381.2010.01126.x)

Tsuei AC \& Martinus RD 2012 Metformin induced expression of Hsp60 in human THP-1 monocyte cells. Cell Stress and Chaperones 17 23-28. (https://doi.org/10.1007/s12192-011-0282-6)

UKPDS Group 1998 Effect of intensive blood-glucose control with metformin on complications in overweight patients with type 2 diabetes (UKPDS 34). UK Prospective Diabetes Study (UKPDS) Group. Lancet 352 854-865. (https://doi.org/10.1016/S0140-6736(98)07037-8)

Vaez H, Najafi M, Rameshrad M, Toutounchi NS, Garjani M, Barar J \& Garjani A 2016 AMPK activation by metformin inhibits local innate immune responses in the isolated rat heart by suppression of TLR 4-related pathway. International Immunopharmacology 40 501-507. (https://doi.org/10.1016/j.intimp.2016.10.002)

Vasamsetti SB, Karnewar S, Kanugula AK, Thatipalli AR, Kumar JM \& Kotamraju S 2015 Metformin inhibits monocyte- to-macrophage differentiation via AMPK-mediated inhibition of STAT3 activation: potential role in atherosclerosis. Diabetes 64 2028-2041. (https://doi. $\operatorname{org} / 10.2337 / \mathrm{db} 14-1225)$

Vazirpanah N, Ottria A, Van Der Linden M, Wichers CGK, Schuiveling M, Van Lochem E, Phipps-Green A, Merriman T, Zimmermann M, Jansen M, et al. 2019 MTOR inhibition by metformin impacts monosodium urate crystal-induced inflammation and cell death in gout: a prelude to a new add-on therapy? Annals of the Rheumatic Diseases 78 663-671. (https://doi.org/10.1136/ annrheumdis-2018-214656)

Wang Q, Zhang M, Torres G, Wu S, Ouyang C, Xie Z \& Zou MH 2017 Metformin suppresses diabetes-accelerated atherosclerosis via the inhibition of Drp1-mediated mitochondrial fission. Diabetes 66 193-205. (https://doi.org/10.2337/db16-0915)

Wang M, Qu S, Ma J, Wang X \& Yang Y 2020 Metformin suppresses LPSinduced inflammatory responses in macrophage and ameliorates allergic contact dermatitis in mice via autophagy. Biological and Pharmaceutical Bulletin 43 129-137. (https://doi.org/10.1248/bpb.b1900689)

Wolf D \& Ley K 2019 Immunity and inflammation in atherosclerosis. Circulation Research 124 315-327. (https://doi.org/10.1161/ CIRCRESAHA.118.313591)

Wu H \& Ballantyne CM 2020 Metabolic inflammation and insulin resistance in obesity. Circulation Research 126 1549-1564. (https://doi. org/10.1161/CIRCRESAHA.119.315896)

Xu W, Deng YY, Yang L, Zhao S, Liu J, Zhao Z, Wang L, Maharjan P, Gao S, Tian Y, et al. 2015 Metformin ameliorates the proinflammatory state in patients with carotid artery atherosclerosis through sirtuin 1 induction. Translational Research 166 451-458. (https://doi. org/10.1016/j.trsl.2015.06.002)

Xu X, Lin S, Chen Y, Li X, Ma S, Fu Y, Wei C, Wang C \& Xu W 2017 The effect of metformin on the expression of GPR109A, NF- $\kappa$ B and IL-1 $\beta$ in peripheral blood leukocytes from patients with type 2 diabetes mellitus. Annals of Clinical and Laboratory Science 47 556-562.

Yan H, Zhou HF, Hu Y \& Pham CTN 2015 Suppression of experimental arthritis through AMP-activated protein kinase activation and autophagy modulation. Journal of Rheumatic Diseases and Treatment 15. (https://doi.org/10.23937/2469-5726/1510005)

Yang Q, Yuan H, Chen M, Qu J, Wang H, Yu B, Chen J, Sun S, Tang X \& Ren W 2018 Metformin ameliorates the progression of atherosclerosis via suppressing macrophage infiltration and inflammatory responses in rabbits. Life Sciences 198 56-64. (https://doi.org/10.1016/j.lfs.2018.02.017)

Ye J, Zhu N, Sun R, Liao W, Fan S, Shi F, Lin H, Jiang S \& Ying Y 2018 Metformin inhibits chemokine expression through the AMPK/ NF- $\kappa \mathrm{B}$ signaling pathway. Journal of Interferon and Cytokine Research $\mathbf{3 8}$ 363-369. (https://doi.org/10.1089/jir.2018.0061)

Zarrouk M, Finlay DK, Foretz M, Viollet B \& Cantrell DA 2014 Adenosinemono-phosphate-activated protein kinase-independent effects of metformin in T cells. PLoS ONE 9 e106710. (https://doi.org/10.1371/ journal.pone.0106710)

Zhang J, Huang L, Shi X, Yang L, Hua F, Ma J, Zhu W, Liu X, Xuan R, Shen Y, et al. 2020 Metformin protects against myocardial ischemia-reperfusion injury and cell pyroptosis via AMPK/NLRP3 inflammasome pathway. Aging 12 24270-24287. (https://doi.org/10.18632/aging.202143)

Zhou G, Myers R, Li Y, Chen Y, Shen X, Fenyk-Melody J, Wu M, Ventre J, Doebber T, Fujii N, et al. 2001 Role of AMP-activated protein kinase in mechanism of metformin action. Journal of Clinical Investigation 108 1167-1174. (https://doi.org/10.1172/JCI13505)

Zhou Z, Tang Y, Jin X, Chen C, Lu Y, Liu L \& Shen C 2016 Metformin inhibits advanced glycation end products-induced inflammatory response in murine macrophages partly through AMPK activation and RAGE/NF B pathway suppression. Journal of Diabetes Research 2016 4847812. (https://doi.org/10.1155/2016/4847812)

Received in final form 23 July 2021

Accepted 31 August 2021

Accepted Manuscript published online 31 August 2021 https://joe.bioscientifica.com https://doi.org/10.1530/JOE-21-0194
(C) 2021 Society for Endocrinology Published by Bioscientifica Ltd. Printed in Great Britain 